\section{In Vitro Fit and Cementation Resistance of Provisional Crowns for Single Implant-Supported Restorations}

Izabela Cristina Maurício Moris, Juliana Elias de Oliveira, Adriana Cláudia

Lapria Faria, Ricardo Faria Ribeiro, Renata Cristina Silveira Rodrigues
Department of Dental Materials and Prosthodontics, Dental School of Ribeirão Preto, USP - University of São Paulo, Ribeirão Preto, SP, Brazil

Correspondence: Renata Cristina Silveira Rodrigues, Avenida do Café, s/n, Monte Alegre, 14040-904 Ribeirão Preto, SP, Brasil. Tel: +55-16-33154005. e-mail: renata@forp.usp.br

\begin{abstract}
This study aimed to verify marginal fit and the effect of cement film thickness standardization on retention of provisional crowns made with prefabricated acrylic cylinders on abutments, using two temporary luting agents subjected or not to mechanical cycling. Provisional crowns were made from bis-acryl (Luxatemp Fluorescence) or methyl methacrylate (Duralay) resins on acrylic cylinders and marginal fit and cement film thickness were evaluated. For retention evaluation, crowns were cemented with two temporary luting agents: non-eugenol zinc oxide (Tempbond NE) or calcium hydroxidebased (Hydcal) cements and subjected to tensile strength in a universal testing machine. After cleaning, debonded crowns were cemented again, subjected to mechanical cycling and retention was reassessed. The results of marginal fit and cement film thickness were analyzed by Student's t-test while retention of cements before and after mechanical cycling was analyzed using a mixed linear model. Methyl methacrylate crowns presented greater marginal misfit $(p=0.001)$ and occlusal cement film thickness $(p=0.003)$ than the bis-acryl ones. No difference was observed at axial cement film thickness $(p=0.606)$. Resins $(p=0.281)$ did not affect crown retention, but luting agents $(p=0.029)$ and mechanical cycling ( $p=0.027)$ showed significant effects. The only significant interaction was mechanical cycling*luting agents, which means that luting agents were differently affected by mechanical cycling $(p=0.002)$. In conclusion, the results showed that bisacryl resin associated to calcium-hydroxide luting agent provided the best retention and lower cement thickness.
\end{abstract}

Key Words: dental cements, acrylic resins, dental restoration temporary, tensile strength.

\section{Introduction}

It is claimed that difficulties related to the use of temporary removable partial dentures or adhesive prosthesis forced the development of techniques aiming to decrease healing period, simplifying the procedure, decreasing the costs and offering comfort for the patients. Based on this fact, immediate loading implants were proposed for provisional prosthesis installation immediately after implant placement, restoring esthetics and function to the patients (1).

Special attention should be devoted to the details that involve provisional prosthesis design and construction in order to achieve successful aesthetic, functional and biological results (2). Provisional prostheses should be the prototype of the final prostheses made from a material able to be repaired or partially prepared for necessary corrections after installation in the mouth (3). For successful provisional prostheses, knowledge of different materials and products available on the market is necessary to optimize the survival rate in use (4).

The retention of cemented crowns can be influenced by several factors such as convergence angle, height and surface roughness of the abutment (5). Different provisional luting agents also offer different levels of retention. Multiple factors in oral environment such as temperature change, $\mathrm{pH}$ and occlusal forces affect properties and retention of provisional luting agents (6). Several studies reported the use of non-eugenol zinc oxide and calcium hydroxidebased luting agents in the clinical practice for temporary cementation of implant-supported crowns (7-11).

The in vitro compressive cyclic loading is a condition that can be used to simulate occlusal stress present in the oral environment, affecting the retention of provisional luting agents and predicting the in vivo behavior of these materials $(12,13)$.

The aim of this study was to evaluate the effect of two materials used for provisional prostheses (methyl methacrylate and bis-acryl composite) on marginal fit and cement film thickness at abutment-cylinder interface when prefabricated cylinders are used for provisional crown construction, and then the effect of two temporary (a calcium-hydroxide and a non-eugenol based) luting agents and mechanical cycling on the retention of these crowns.

The work hypotheses were: 1- the material used for provisional crown construction would not interfere on the marginal fit and cement film thickness; and 2- luting agent and mechanical cycling would not affect the crown retention. 


\section{Material and Methods}

The present study was divided in two parts. In the first part, provisional crowns were made with two different resins and their fit was evaluated. In the second part, these provisional crowns were divided into two groups according to the temporary luting agent to be used and the retention was evaluated before and after mechanical cycling.

\section{PART 1}

Morse taper implants 4.3 x $13 \mathrm{~mm}$ (Titamax CM; Neodent, Curitiba, PR, Brazil) were positioned in a stainlesssteel matrix (20 mm diameter $\times 20 \mathrm{~mm}$ high), with internal walls that matched implant external dimensions. For implant locking, a fixation screw was tightened in a lateral hole of the matrix ensuring implant stability against lateral and rotational movements. Universal abutments $4.5 \times 4.0 \times 1.5$ $\mathrm{mm}$ (Neodent) were installed on the implants with the recommended insertion torque of $32 \mathrm{Ncm}$ using a digital torque meter (TQ 680; Instrutherm, São Paulo, SP, Brazil). Twenty four matrix-abutment-implant sets were made.

\section{Provisional Crown Construction}

Twenty-four cylinders for universal abutment (CM $4.5 \times 4.0 \mathrm{~mm}$, Neodent) were used to make the provisional crowns. The cylinders were divided in two groups according to the resin used for provisional crowns (Fig. 1). In Group 1, provisional crowns were made using methyl-methacrylate resin (Duralay; Reliance Dental Mgf. Co., Alsip, IL, USA) (DUR) $(n=12)$ while in Group 2, was used a bis-acryl composite resin (Luxatemp Fluorescence; DMG Dental Material Gesellschaft, Hamburg, Germany) (LUX) ( $n=12)$. A crown was waxed on a cylinder following the axial alignment. Then, to standardize crown construction, a condensation silicon mold (Zetaplus; Zhermack, Rovigo, Italy) was fabricated

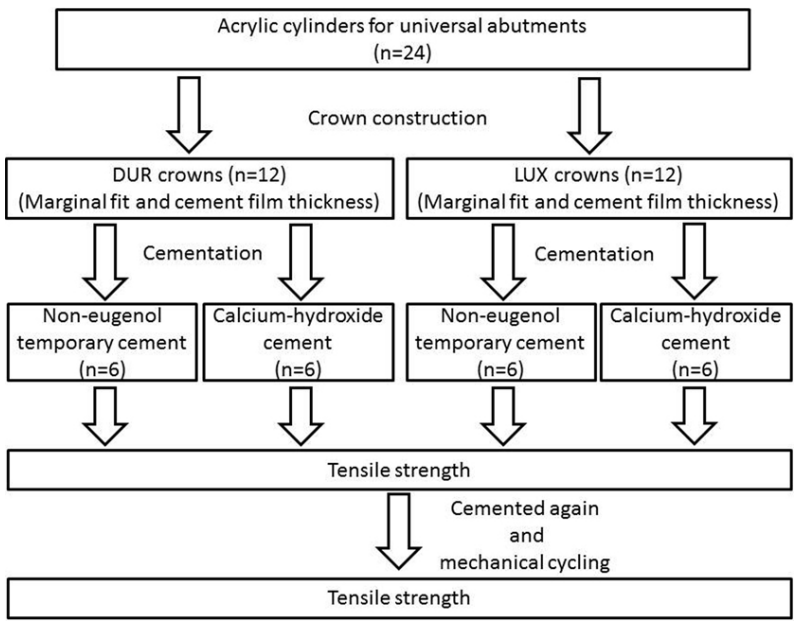

Figure 1. Chart representing study sequence from acrylic cylinders to tensile strength after mechanical cycling. involving wax crown and stainless-steel cylinder where implants and abutments were installed. The mold was divided into two parts and remounted at the moment of resin application on cylinders to obtain similar provisional crowns. Provisional crowns were stored in distilled water at $37^{\circ} \mathrm{C}$ until the tests were performed.

\section{Cement Film Thickness and Marginal Fit}

The cement film thickness at the interface of the provisional crown and the universal abutment was evaluated according to previous study (14). A polyvinyl siloxane light impression material (Honigum-Light; DMG) was applied in the provisional crown that was placed on the abutment for 5 min under a $4 \mathrm{~N}$ load using a dental surveyor (Fig. 2A). After impression material curing, the provisional crown was removed and A polyvinyl siloxane medium impression material (Honigum-Mono; DMG) with contrasting color was applied in its inside until complete filling, This impression was positioned in a matrix, the provisional crown was removed (Fig. 2B), and more polyvinyl siloxane medium impression material was added to embed the first impression (cement film thickness). This set was divided in two parts, and each part was analyzed using a S8AP0 stereomicroscope (Leica Microsystems, Heerbrugg, Switzerland) with a digital camera DFC250 (Leica) in a 40x magnification. The cement film thickness was measured on the occlusal and axial faces (Fig. 2C).
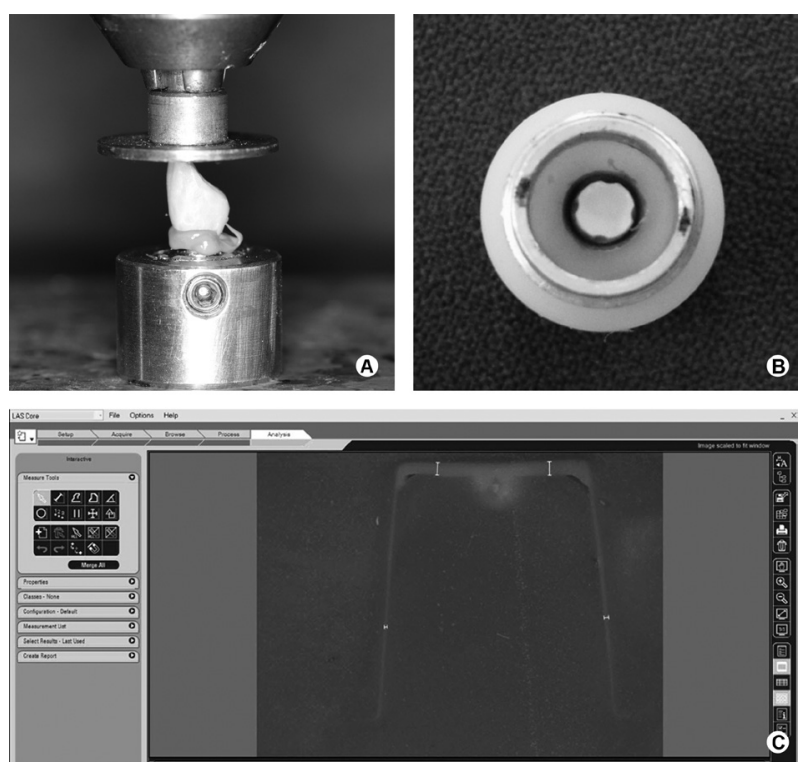

Figure 2. Method used for evaluation of cement film thickness. ACrown with polyvinyl siloxane light impression material film inside; B- Set positioned in another matrix after cylinder removal. A ring was coupled and markings were used to identify the buccal-lingual limit; C- Image of piece of polyvinyl siloxane medium impression material presenting polyvinyl siloxane light impression material (cement film thickness) inside after cut following buccal-lingual limit. Lines indicate tool used for measuring cement film thickness in the software and the analyzed regions. 
Marginal fit of the provisional crowns to universal abutment was measured. Three measures were performed in four regions (buccal, lingual, mesial and distal faces), and an optical microscope (Nikon, Kogaku, Japan) was used in a $15 \times$ magnification. The mean value of marginal fit was used for analysis.

The marginal fit and cement film thickness at axial and occlusal faces were analyzed by Student's t test for independent samples using IBM SPSS software (IBM Corporation, Somers, NY, USA).

\section{PART 2}

\section{Provisional Crown Retention}

Provisional crowns of DUR or LUX resin were subdivided in two groups according to the used temporary luting agent: non-eugenol zinc oxide-based (Temp Bond NE; Kerr, Orange, CA, USA) (TB) or calcium hydroxide-based (Hydcal; Technew, Rio de Janeiro, RJ, Brazil) (HC). Each luting agent was manipulated according to manufacturers' recommendations and provisional crowns were placed under digital pressure simulating clinical procedure. After cementation, samples were stored in $100 \%$ relative humidity environment for $24 \mathrm{~h}$ at $37{ }^{\circ} \mathrm{C}(6,9,10)$ and subjected to $\vec{s}$ tensile strength test with a $500 \mathrm{kgf}$ load cell in a universal testing machine EMIC MEM 2000 (EMIC, São Jose dos Pinhais, PR, Brazil) at a $0.5 \mathrm{~mm} / \mathrm{min}$ crosshead speed. After testing, the samples were ultrasonically cleaned, cemented again, stored in $100 \%$ relative humidity environment for $24 \mathrm{~h}$ at $37^{\circ} \mathrm{C}$, and subjected to mechanical cycling.

\section{Mechanical Cycling}

For mechanical cycling, stainless-steel matrix-implantuniversal abutment-provisional crown sets were positioned in the electromechanical fatigue test machine (MSFM Termo; Elquip, São Carlos, SP, Brazil). The equipment was calibrated to operate under a $50 \mathrm{~N}$ static load and $2 \mathrm{~Hz}$ frequency, performing 500,000 cycles, which represents 18 months' clinical use (15). Samples were loaded individually and remained immersed in deionized water at $37 \pm 1{ }^{\circ} \mathrm{C}$ during the test. After mechanical cycling, samples were submitted to tensile strength test as described above for the evaluation of retention.

The retention data of provisional crowns with two

Table 1. Marginal fit values $(\mu \mathrm{m})$ of provisional crowns made using DUR or LUX resin

\begin{tabular}{lcc}
\hline Groups & LUX & DUR \\
\hline Marginal fit & $18.5(7.2) \mathrm{A}$ & $60.6(33.2) \mathrm{B}$ \\
\hline
\end{tabular}

Results are presented as mean (standard deviation). Different letters indicate statistically significant difference $(p<0.05)$. temporary luting agents before and after mechanical cycling was analyzed using a mixed linear model with IBM SPSS software. This model, which is a generalization of the standard linear model (ANOVA), is used in the analysis of data in which the responses (retention) of the same specimen are grouped (before and after mechanical cycling), and assumption of independence among the observations in the same group is not adequate. There was one factor with two levels within group (before and after mechanical cycling) and two factors (cements and resins) with two levels ( $\mathrm{HC}$ and $\mathrm{TB} / \mathrm{LUX}$ and DUR) between groups. To use this model, it is required that the errors have a normal distribution with mean zero and constant variance. Differences were considered significant when $p<0.05$. Additionally, cement film thickness/marginal fit and retention results were submitted to Pearson's correlation test $(p<0.05)$.

\section{Results}

The marginal fit data are presented in Table 1. The marginal fit of provisional crowns made of DUR was greater than LUX $(p=0.001)$.

The cement film thickness data are presented in Table 2. The cement film thickness at axial face $(p=0.606)$ of DUR and LUX provisional crowns was statistically similar, but different on occlusal face ( $p=0.003$ ).

The retention measured by tensile strength values (Table 3) and its statistical comparison (Table 4) demonstrated that retention was affected by temporary luting agents and mechanical cycling, but the resins did not interfere with retention. The only significant interaction was mechanical cycling*luting agents, which means that temporary luting agents were differently affected by mechanical cycling. Crowns cemented with $\mathrm{HC}$ improved their retention after mechanical cycling regarding the used resins while TB retention was not affected by cycling.

Retention (before or after mechanical cycling) was not correlated to cement film thickness or marginal fit $(p>0.05)$.

\section{Discussion}

The work hypotheses were rejected because the provisional crown material interfered on the marginal fit

Table 2. Cement film thickness values $(\mu \mathrm{m})$ of provisional crowns made using LUX or DUR resin at axial and occlusal faces

\begin{tabular}{lcc}
\hline Groups & Axial & Occlusal \\
\hline LUX & $97.6(31.4) \mathrm{A}$ & $286.4(53.1) \mathrm{A}$ \\
DUR & $104.5(32.5) \mathrm{A}$ & $679.4(353.3) \mathrm{B}$ \\
\hline
\end{tabular}

Results are presented as mean (standard deviation). Different letters within columns indicate statistically significant difference $(p<0.05)$. 
and cement film thickness at occlusal face; retention was affected by luting agent and mechanical cycling.

Acrylic cylinders for universal abutments promise to be an advance in construction of provisional crowns because components are prefabricated and the procedure can be simplified by minimizing relining requirement. In the current study cylinders were used as base and resins were added to make the provisional crowns; some parameters such as marginal fit, cement film thickness and retention were evaluated after provisional crown construction.

In the present study, DUR provisional crowns presented greater marginal misfit than LUX crowns. This difference may be attributed to the polymerization shrinkage of different resins which causes dimensional changes of the temporary restoration (16). Materials based on monomethacrylates are usually supplied as powder/liquid and their shrinkage is dependent on the powder/liquid ratio. The addition of more liquid to the mix increases shrinkage $(16,17)$. The same power/liquid ratio has been used in the present study even though the ratio of power/ liquid was not provided by the manufacturer. On the other hand, bis-acryl resins are provided by the manufacturer in cartridges of self-mix system ensuring material availability in the correct proportions (16). Then, the probable reason for the higher variability in marginal fit of DUR provisional crowns is the lack of manufacturer information on the correct material proportion. In addition, the filling particles in the composition of bis-acryl resins decrease the fraction of monomer required for the polymerization, decreasing polymerization shrinkage (16). Therefore, the marginal misfit appears to be consequence.

Although some difference was noted between the marginal fit of the restorations made with different resins, marginal misfits observed in the present study were less than $90 \mu \mathrm{m}$, a positive aspect for the evaluated materials which reproduced provisional crowns whose misfit was lower than those considered acceptable in the literature. Some studies related misfits around $900 \mu \mathrm{m}(18,19)$, a great

Table 3. Provisional retention (N) of LUX or DUR crowns cemented with different provisional luting agents before and after mechanical cycling

\begin{tabular}{lccc}
\hline Resin & Luting agent & Before & After \\
\hline \multirow{2}{*}{ LUX } & HC & $24.5(4.8)$ & $56.9(29.5)$ \\
& TB & $37.7(16.1)$ & $32.4(21.9)$ \\
& & & \\
DUR & HC & $28.0(11.9)$ & $55.1(25.5)$ \\
& TB & $25.3(11.2)$ & $16.4(5.6)$ \\
\hline
\end{tabular}

Results are presented as mean (standard deviation). value compared to the acceptable values of 50 to $100 \mu \mathrm{m}$ (20). The reason for this difference in relation to other studies is probably due to the use of acrylic cylinder that acts minimizing misfit. Because the cylinder is provided by the manufacturer, strict standardization is expected and better fit of cylinder and universal abutments subject to less influence of polymerization shrinkage than crowns obtained without the cylinder. Further studies comparing fit of provisional crowns that used or not acrylic cylinders for crown construction are expected to answer this question.

The volumetric shrinkage can also generate stress inside the restorations, mainly on axial and occlusal faces (16). In the present study, the cement film thickness was affected on occlusal face by the resin used for provisional restoration. Nevertheless, greater misfit and occlusal cement film thickness of DUR crowns did not imply in less retention as proved by the correlation test.

Crown retention was not affected by materials used for provisional construction in the current study, as other studies affirm that retention is not affected by the material used for provisional crowns $(10,21)$. On the other hand, there is no concern in the literature about the effect of the temporary luting agent. If there is a study relating difference of retention between calcium-hydroxide and non-eugenol zinc oxide-based cements (22), it is related

Table 4. Statistical comparison

\begin{tabular}{|c|c|c|c|c|}
\hline Comparison & Resins & $\begin{array}{l}\text { Luting } \\
\text { agents }\end{array}$ & $\begin{array}{l}\text { Mechanical } \\
\text { cycling }\end{array}$ & $p$ value \\
\hline Resins & LUX=DUR & & & 0.281 \\
\hline Luting agents & & $\mathrm{HC}>\mathrm{TB}$ & & 0.029 \\
\hline Cycling & & & Before $<$ After & 0.027 \\
\hline \multirow{3}{*}{$\begin{array}{l}\text { Resins } x \text { Luting } \\
\text { agents }\end{array}$} & & & & 0.225 \\
\hline & DUR & $\mathrm{HC}>\mathrm{TB}$ & & 0.017 \\
\hline & LUX & $\mathrm{HC}=\mathrm{TB}$ & & 0.453 \\
\hline \multirow{3}{*}{ Resins x Cycling } & & & & 0.610 \\
\hline & DUR & & Before=After & 0.190 \\
\hline & LUX & & Before $=$ After & 0.059 \\
\hline \multirow{3}{*}{$\begin{array}{l}\text { Luting agents } \\
\text { x Cycling }\end{array}$} & & & & 0.002 \\
\hline & & $\mathrm{HC}$ & Before $<$ After & 0.000 \\
\hline & & TB & Before $=$ After & 0.381 \\
\hline \multirow{5}{*}{$\begin{array}{l}\text { Resins } \times \text { Luting } \\
\text { agents } \times \text { Cycling }\end{array}$} & & & & 0.994 \\
\hline & \multirow{2}{*}{ DUR } & $\mathrm{HC}$ & Before $<$ After & 0.010 \\
\hline & & TB & Before=After & 0.365 \\
\hline & \multirow{2}{*}{ LUX } & $\mathrm{HC}$ & Before $<$ After & 0.003 \\
\hline & & ТВ & Before=After & 0.717 \\
\hline
\end{tabular}


similarly in another study (10). The present study agrees with the last study because crowns cemented with $\mathrm{HC}$ presented greater retention than TB. Several studies showed that non-eugenol zinc oxide-based cements are the least retentive among temporary cements $(22,23)$ especially when abutments were not prepared or rough (8), as in the present study.

The temporary luting agents evaluated in this study presented different behavior when provisional crowns were submitted to tensile strength test before and after mechanical cycling depending on the materials used to make the crowns. According to some authors, the increased number of compressive cycles is able to improve retention (13) while others argued that there is no correlation between an increased number of loading cycles and decreased retentive forces. (12) Thus, in the present study great number of mechanical cycles was not used.

In this study the significant interaction mechanical cycling*luting agents means that temporary luting agents were differently affected by mechanical cycling. This suggests that different results of several studies are probably due to the materials used for cementation. Additionally, it is difficult to compare the retention among different $\vec{s}$ studies, because there are several abutment designs with different degrees of taper and surface roughness $(5,13)$ affecting retention irrespective the used cement or cycling.

Crowns cemented with $\mathrm{HC}$ improved their retention after mechanical cycling but TB retention was not affected by cycling, as observed in previous study (7). Mechanical cycling may introduce stress at the crown interface, but retention is not correlated to flexural strength for noneugenol zinc oxide-based cements (9). Although calcium hydroxide-based cements have been used as temporary luting agents $(7,10)$, there is little information available in the literature correlating its mechanical properties and retention. However, it has been suggested that mechanical strength of commercial luting agents could not be a predicting factor for crown retention to implant abutments (11). Further studies are required to help understanding the luting agent's behavior.

It was concluded that bis-acryl composite (LUX) restorations used with calcium-hydroxide cement $(\mathrm{HC})$ provide greater retention for clinical application.

\section{Resumo}

0 objetivo deste estudo foi avaliar a adaptação marginal e o efeito da espessura da camada de cimento na retenção de coroas provisórias fixadas sobre os pilares com o auxilio de cilindros acrílicos pré-fabricados, utilizando dois cimentos provisórios submetidos ou não à ciclagem mecânica. Coroas provisórias foram confeccionadas com resina bis-acrilica (Luxatemp Flourescence) ou resina à base de metil metacrilato (Duralay) sobre os cilindros, para posterior avaliação da influência das diferentes resinas na adaptação marginal e na espessura da linha do cimento. Para a avaliação da resistência à tração, as coroas foram cimentadas com dois cimentos provisórios: à base de óxido de zinco sem eugenol (Temp Bond $\mathrm{NE}$ ) ou hidróxido de cálcio (Hydcal) e submetidas ao teste de tração em máquina universal de ensaio. Após o ensaio, as coroas foram limpas e novamente cimentadas para serem submetidas à ciclagem mecânica e posterior avaliação da resistência à tração. Os resultados obtidos para adaptação marginal e espessura do cimento foram analisados pelo teste t de Student, enquanto os resultados de resistência à cimentação antes e após a ciclagem mecânica foram analisados pelo modelo linear de efeitos mistos. As coroas confeccionadas com a resina de metil metacrilato apresentaram maiores valores para desadaptação marginal $(p=0,001)$ e espessura do cimento $(p=0,003)$ na parede oclusal quando comparadas com as coroas de resina bis-acrilica. Não houve diferença na espessura do cimento $(p=0,606)$ na parede axial das coroas provisórias. As diferentes resinas não afetaram a resistência à cimentação das coroas $(p=0,281)$, mas os diferentes cimentos $(p=0,029)$ e a ciclagem mecânica $(p=0,027)$ mostraram efeitos significantes. A única interação significante foi ciclagem mecânica * agente cimentante, o que significa que os cimentos foram diferentemente afetados pela ciclagem mecânica $(p=0,002)$. Em conclusão, a associação resina bis-acrílica e cimento de hidróxido de cálcio proporcionou melhor resistência à tração e menor espessura de cimento.

\section{Acknowledgments}

The authors thank the São Paulo Research Foundation (grant \#2009/075693) and PIBIC-CNPq for the financial support and Mr. Luiz Sérgio Soares for technical support and Neodent by supplying the implants and components.

\section{References}

1. Taylor TD, Agar JR. Twenty years of progress in implant prosthodontics. J Prosthet Dent 2002;88:89-95.

2. Derbabian $K$, Marzola $R$, Donovan TE, Cho GC, Arcidiacono A. The science of communicating the art of esthetic dentistry. Part II: Diagnostic provisional restorations. J Esthet Dent 2000;12:238-247.

3. Beuer F, Schweiger J, Edelhoff D, Sorensen JA. Reconstruction of esthetics with a digital approach. Int J Periodontics Restorative Dent 2011;31:185-193.

4. Agustin-Panadero R, Serra-Pastor B, Roig-Vanaclocha A, RómanRodriguez JL, Fons-Font A. Mechanical behavior of provisional implant prosthetic abutment. Med Oral Patol Oral Cir Bucal 2015;20:e94-e102.

5. Schiessl C, Schaefer I, Winter C, Fuerst J, Rosentritt M, Zeman F, et al.. Factors determining the retentiveness of luting agents used with metal- and ceramic-based implant components. Clin Oral Investing 2013;17:1179-1190.

6. Hebel KS, Gajjar RC. Cement retained versus screw-retained implant restorations: achieving optimal occlusion and esthetics in implant dentistry. J Prosthet Dent 1997;77:28-35.

7. Akashi $A E$, Francischone $C E$, Tokutsume $E$, da Silva $W$ Jr. Effects of different types of temporary cements on the tensile strength and marginal adaptation of crowns on implants. J Adhes Dent 2002;4:309315.

8. Kim Y, Yamashita J, Shotwell JL, Chong KH, Wang HL. The comparison of provisional luting agents and abutment surface roughness on the retention of provisional implant-supported crowns. J Prosthet Dent 2006;95:450-455.

9. Lawson NC, Burgess JO, Mercante D. Crown retention and flexural strength of eight provisional cements. J Prosthet Dent 2007;98:455460.

10. Lepe $X_{1}$ Bales DJ, Johnson GH. Retention of provisional crowns fabricated from two materials with the use of four temporary cements. J Prosthet Dent 1999;81:469-475.

11. Nagasawa $Y$, Hibino $Y$, Nakajima $H$. Retention of crowns cemented on implant abutments with temporary cements. Dent Mater J 2014;33:835-844.

12. Dudley JE, Richards LC, Abbott JR. Retention of cast crown copings cemented to implant abutment. Aust Dent J 2008;53:332-339.

13. Ongthiemsak C, Mekayarajjananonth T, Winkler S, Boberick KG. The effect of compressive cyclic loading on retention of a temporary 
cement used with implants. J Oral Implantol 2005;1:115-120.

14. Mc Lean JW, Von Fraunhofer JA. The estimation of cement film thickness by an in vivo technique. Br Dent J 1971;131:107-111.

15. Craig RG. Restorative dental materials. 9th ed. St Louis: Mosby; 1993.p. 75-77.

16. Kim SH, Watts DC. Polymerization shrinkage-strain kinetics of temporary crown and bridge materials. Den Mater 2004;20:88-95.

17. Mojon P, Oberholzer JP, Meyer JM, Belser U. Polymerization shrinkage of index and pattern acrylic resins. J Prosthet Dent 1990;64:684-688.

18. Stansbury JW, Trujillo-Lemon M, Lu H, Ding X, Lin Y, Ge J. Conversiondependent shrinkage stress and strain in dental resins and composites. Dent Mater 2005;21:56-67.

19. Tjan AH, Castelnuovo J, Shiotsu G. Marginal fidelity of crowns fabricated from six proprietary provisional materials. J Prosthet Dent 1997;77:482-485.
20. Wang RL, Moore BK, Goodacre CJ, Swartz ML, Andres CJ. A comparison of resins for fabricating provisional fixed restorations. Int J Prosthodont 1989;2:173-184.

21. Nejatidanesh F, Lotfi HR, Savabi O. Marginal accuracy of interim restorations fabricated from four interim autopolymerizing resins. $J$ Prosthet Dent 2006;95:364-367.

22. Rego MR, Santiago LC. Retention of provisional crowns cemented with eight temporary cements: comparative study. J Appl Oral Sci 2004;12:209-212.

23. Güncü MB, Cakan $U$, Canay $S$. Comparison of 3 luting agents on retention of implant-supported crowns on 2 different abutments. Implant Dent 2011;20:349-353.

Received May 12, 2014

Accepted June 16, 2015 